\title{
Participatory diagnosis of the tourism sector in managing the crisis caused by the pandemic (COVID-19)
}

\section{Diagnóstico participativo del sector turístico en el manejo de la crisis provocada por la pandemia (COVID-19)}

Ángel Félix ${ }^{1 *}$, Nelson García Reinoso ${ }^{2} \&$ Rafael Vera ${ }^{3}$

\footnotetext{
${ }^{1}$ Master in Planning and Management of Ecolological and Agrotourism Projects, Department of Tourism, ESPAM MFL, Calceta-Manabí, Ecuador

${ }^{2}$ Master in Tourism Management, Department of Tourism, ESPAM MFL, Calceta-Manabí, Ecuador

${ }^{3}$ Master in Sustainable Management of Tourism Destinations, Department of Tourism, ESPAM MFL, Calceta-Manabí, Ecuador

* Corresponding author: afelixવespam.edu.ec
}

\section{ABSTRACT}

COVID-19 pandemic has plunged the entire world into a crisis, that is causing aggressive changes in the world economic system, particularly of those immersed in tourism. This work identifies the strategies and groups of strategies that entrepreneurs and businessmen of the Manta - Ecuador tourism sector need for their businesses survival. For the information gathering, a questionnaire with open-ended questions was applied and disseminated with the help of the local government, through mailing and WhatsApp groups of registered associations. A response was obtained from $48 \%$ of the establishments registered in the city. The qualitative information collected was processed by using the Atlas Ti software, which resulted in the identification of 14 codes (strategies) that were classified into two codes groups (strategies groups). The strategies have different relationships; therefore, they are addressed to two groups, the first one implies actions that should be performed by authorities to improve the city's tourism management model and the second one, actions specific to the sector for the improvement of the health and bio-security processes in tourist establishments.

Keywords: COVID-19, tourism, resilience, pandemics.

\section{RESUMEN}

La pandemia del COVID- 19 ha sumergido al mundo entero en una crisis, la cual está provocando profundos cambios en el sistema económico mundial, inmersos en ellos la actividad turística. El presente documento identifica las estrategias y grupos de estrategias que necesitan los empresarios del sector turístico de Manta - Ecuador para la supervivencia. Para realizar el levantamiento de información, se utilizó un cuestionario con preguntas de respuestas abiertas y de selección múltiple, el mismo fue difundido con la ayuda del gobierno local, mediante mailing y grupos de WhatsApp de las asociaciones catastradas. Se obtuvo respuesta del $48 \%$ de los establecimientos catastrados en la ciudad. El contenido informativo cualitativo fue procesado mediante el software Atlas Ti dando como resultado la identificación de 14 códigos (estrategias) y fueron encasillados en dos grupos de códigos (grupo de estrategias). Las estrategias tienen diversas relaciones, por ello están orientadas por una parte al primer grupo (acciones de las autoridades), a mejorar el modelo de gestión turística de la ciudad y en el grupo dos (acciones propias del sector), a la mejora de los procesos de salud y bio seguridad en los establecimientos turísticos.

Palabras clave: COVID-19, turismo, resiliencia, pandemias. 


\section{INTRODUCTION}

The importance of tourism activity worldwide derives from its powerful capacity to stimulate international economies through international transit of people, which represents for the recipient countries interest-free incomes. During 2009, international tourist visits (overnight visitors) worldwide grew by $4 \%$ to reach 1.5 billion (UNWTO, 2020).

Growth was slightly slower compared to the previous years $2017(+7 \%)$ and $2018(+6 \%)$ in the wake of geopolitical and trade tensions, caused by changes in the system in response to the collapse of Thomas Cook and several lowcost airlines in Europe (UNWTO, 2020). Based on current trends, the economic outlook and the UNWTO Confidence Index, 3\% to 4\% growth in international tourist arrivals worldwide was forecast in 2020 (UNWTO, 2020). However, none of this will happen, due to the presence of a new and dangerous enemy for world tourism activity, the Corona Virus Disease 2019 (COVID-19).

Back on December 27, 2019, in the Chinese province of Wuhan, the first case of a patient affected by COVID-19, caused by Coronavirus 2 of Severe Acute Respiratory Syndrome (SARS-CoV-2) was reported (Rodríguez-Morales et al., 2020). Two months later, on February 25 this year, Latin America was reached by this virus. That day, The Brazilian Ministry of Health confirmed the first case of a 61-year-old Brazilian man who had traveled between the 9 and 20 of February, 2020, from Brazil to Lombardy, in northern Italy, where a significant outbreak of the disease had occurred, (Rodríguez-Morales et al., 2020).

The disease was so aggressive that it quickly became a pandemic, being transported by travelers around the world, especially by those who chose to return to their countries, scared by international news. International concern about this situation rapidly increased and on $\mathrm{Fe}$ bruary 26, "the World Tourism Organization (UNWTO) and the World Health Organization (WHO) worked closely with each other to help states ensure that sanitary measures were implemented in a way that reduces any unnecessary interference with international traffic and trade" (UNWTO, 2020b).

Today, many countries around the world are carrying out strict quarantines, so that all social and economic activi- ties have completely stopped, generating an unprecedented recession. Tourism is one of the most affected activities and it is expected to be one of those that will take the longest to recover.

Many tourism destinations around the world are in a difficult scenario are, where the main problems start with their local businessmen, who are waiting for guidelines to be provided by local authorities to cope with this crisis. The UNWTO (2020c) encourages the employment care in the sector, providing guidelines for it, but they are very difficult to implement, due to the socio-economic realities of each territory.

This is the situation of the canton of Manta, located in the center of the province of Manabí - Ecuador it has an airport and an international port, the second is regularly visited by tourists from all over the world, as it is a key site in the itinerary of visits of several cruise ship lines with routes in the pacific. Manta has an official plant of 569 tourist establishments, they are facing serious problems and economic losses because of the social isolation measures, as a result of the spread of the COVID-19 pandemic, at the present time the different tourist actors, especially the businessmen and entrepreneurs need solutions and response actions to sustain their businesses and activities. The present research tries to gather the first impressions of the tourist businessmen in Manta, taking into account their projections in diverse areas such as: job stability, search for incentives and possible recovery strategies.

\section{Tourism and pandemics}

Endemics, epidemics and pandemics have existed throughout history, obtaining from them new lessons for each of the civilizations that have experienced them (Ledermann, 2003). For instance, during the new century there have been several diseases that have shocked the entire planet with regard to the number of infections, deaths and economic losses such as: SARS, Ebola, swine flu (H1N1) and the current COVID-19 (Arrazola, Serrano, \& López-Vélez, 2016).

The affectations of these epidemics have directly affected the world economies and therefore, among the most 
severely affected sectors is tourism (Dávila et al., 2010). According to Guardia (2020) relying on data by the World Health Organization, the diseases that have affected the most are those listed in Table 1.

Table 1. Incidence of pandemics in the world.

\begin{tabular}{|c|c|c|c|}
\hline Disease & Deaths & Region & Losses \$ \\
\hline SARS & 7740 & $\begin{array}{l}\text { Asia, The North } \\
\text { of America, South } \\
\text { America, Europe }\end{array}$ & 40 million \\
\hline H1N1 & 18641 & around the world & 50 million \\
\hline EVD & 11308 & $\begin{array}{l}\text { Africa, The North } \\
\text { of America, United } \\
\text { Kingdom and Italy }\end{array}$ & 53 million \\
\hline COVID-19 & $\begin{array}{c}199,874 \\
25 / 04 / 20\end{array}$ & around the world & $\begin{array}{l}\text { It is } \\
\text { estimated } \\
\text { around } \\
280.000 \\
\text { million }\end{array}$ \\
\hline
\end{tabular}

Source: Prepared by the authors from Guardia (2020)

Pandemics are strongly related to tourism due -in the first place- to the limited transit of international passengers, so the first impact is related to the closure of borders to avoid massive contagion (Arrazola et al., 2016; Cortés, 2019; Dávila et al., 2010). Second, there is fear on the part of travelers and prohibitions on the mobilization from their habitual place of residence, which entails strict measures by governments to counteract infections (Ledermann, 2003; Leggat, Brown, Aitken, \& Speare , 2010; Oehmichen \& Pombo, 2010).

A chronological review on the new millennium pandemics and their effects on the tourism industry is briefly presented in this study. In the first instance, reference is made to SARS, on April 2, 2003 when the WHO declares the southern Chinese provinces of Guangzhou and Hong Kong as high-risk tourist destinations (Jamal \& Budke, 2020). This triggered a great restriction of tourist flows, both for the entry and exit of visitors to these areas (Zeng, Carter, \& De Lacy, 2005).

The closest reference to Latin American countries comes hand in hand with the H1N1 influenza in 2009 in Mexi- co that severely affected the image of that destination. This country can be seen as a catalyst for tourism in Latin America, the insecurity of traveling to this destination caused the exits of tourists and the cancellation of dozens of flights to and from Mexico. The appearance of this virus -unknown until then- also displayed the fragility of the tourism economy. (Oehmichen \& Pombo, 2010).

Another precedent of deadly contagious diseases within the new millennium, is the Ebola (EVD), which had an shocking outbreak, between the end of 2013 and October 2014, leaving a total of 10,141 infections in 6 countries in different continents: America, Europe and Africa (Africa Research Bulletin, 2014). This fact resulted in the cancellation of important air traffic frequencies to several important African capitals, causing a shock to the image of African tourist destinations, as they were believed to be unsafe. On account of the ethnic and cultural similarities of the countries of this region, what happens in one country affects them all (Maphanga \& Henama, 2019). This is very recurrent in regions that have been promoted under the same advertising umbrella, as in the Central American Caribbean.

Against this background, some points are highlighted to remain as lessons learned from pandemics, such as: close cooperation between tourism stakeholders including service providers and destination management organizations and public health authorities; all this together with an increased responsibility on the part of residents and tourists to search for correct data on the disease and to take reasonable precautions, as it is recommended in crisis management and recovery studies (Jamal and Budke, 2020).

\section{Crisis management models in tourism.}

Tourism is a sector that is affected by multiple factors, and one of the most powerful ones is vulnerability to different phenomena, since it develops within a geographic space, therefore it is subjected to fortuitous changes. Phenomena include: political instability / riots, likelihood of terrorism, crime rates, transportation security record, corruption of police / administrative services, quality of sanitation, prevalence of disease outbreaks, unreliability of medical services, and availability of medications (Dwyer \& Kim, 2003)

The outbreak of a deadly virus, the collapse of the economy, or environmental catastrophes such as hurricanes 
and earthquakes can create sudden discontinuities in the pattern of tourist flows (Crouch \& Ritchie, 1999). Indeed, nothing can influence traveler choices more powerfully and clearly than concerns about safety and security (Ritchie \& Crouch, 2010).

Situations of crises that have affected tourism are varied. For instance, since November 11, 2020, studies on this issues were massified, trying to provide researchers with theoretical and conceptual tools to provide references through case studies related to these type of conditions (Faulkner , 2001). A new trend has been generated in tourism research, related to studying issues such as tourism resilience and the reconstruction of the tourism sector (Basurto-Cedeño \& Pennington-Gray, 2018; Birkland, Pannapa, Little, \& Wallace, 2006; Félix, Campos, Martí, \& Ramos, 2017).

In this context, there is a great variety of conceptual models that have been proposed to organize actions for their implementation in territories before, during and after an affectation (Ritchie, 2004). However, these models lack proven effectiveness in practice, so they can be differentiated, on the one hand, the models produced by academic studies that propose differentiated stages and strategies for crisis management, such as the 4-R model (Wilks and Moore, 2003 ; De Sausmarez, 2004; Pennington et al., 2010) and on the other, there are management models that are focused on territorial planning and contribute to a greater number of stages that include preparing for the event, and other valuable contributions among which relevant references may be found (Faulkner, 2001; Evans and Elphic, 2005 ; Paraskevas \& Altinay, 2013; Ritchie, 2004; Rivera \& Félix, 2019).

As a matter of fact, there are situations when International Organizations have collaborated in the management of various crises at a global level, relying on their experience, they propose models which embody prevention and the rapid reaction of the system to the crisis. For instance, the United Nations Programs for Development and Environment (UNDP-UNEP), based on its experience in crisis managing in various countries worldwide, it has identified four fundamental phases: Prevention, Preparedness, Response and Recovery (UNDP-UNEP, 2008; UNEP, 2008).

The study and comparative analysis of experiences worldwide, both theoretical and practical, on the recovery and planning of tourism destinations affected by crises of any origin, must be adopted as part of the emergency processes of tourist destinations, for the adoption of adequate response strategies, adapted to the different phases of the recovery process. (Rivera \& Félix, 2019). In particular, the study of these international experiences can serve to adopt measures that increase the resilience of tourist destinations both from the environmental and socioeconomic points of view in the face of disasters, as well as to identify the most suitable guidelines to integrate the general management of these natural catastrophes in the planning and tourist development of the territory (Félix \& Rivera, 2018).

\section{Strategies applied to tourism (COVID-19)}

Once the COVID-19 pandemic was declared, all the organizations involved in tourism worldwide began their race against time in order to generate action guidelines for all the actors in the industry.

In connection with that situation, at the beginning of this year, the WHO released several health and contingency releases, particularly regarding the tourism sector and COVID-19. For instance, on January 10, it released a statement titled: WHO Advice on International Travel and Trade in relation to the pneumonia outbreak caused by the new coronavirus through which they established clinical signs and symptoms (fever, dyspnea and infiltrates in both lungs) manifested by infected patients, for this reason it was recommended to international travelers to take ordinary practical precautions such as: avoid direct contact with people suffering from acute respiratory infections, wash their hands frequently, specifically after contact with sick people or their environment; avoid direct contact with wild (living or dead) animals. Indeed, people with symptoms of an acute respiratory infection should take the following precautions: keep a certain distance from others, cover their nose and mouth with disposable tissues or clothing when sneezing or coughing, and wash their hands (WHO, 2020).

On the other hand, the UNWTO manifested its concern through several releases since the beginning of this year 2020, by means of which it seeks to ensure a future good functioning of the industry. However, some of them disagree with reality for decision-making in many countries around the world, where the characteristics of their territory, their fragile economic system or their socio-cultural schemes, make it very difficult to put such guidelines into practice. The main releases are listed below in chronological order: 
Travelers are obliged to inform themselves "before traveling, to reduce the risk of transmission and they should also follow the recommendations of the WHO and the health authorities of their respective countries" (UNWTO, 2020b).

"No restriction on travel and trade was recommended, based on the information available, it was requested to ensure that sanitary measures are implemented in a manner that minimizes any unnecessary interference with international traffic and trade at the time" (UNWTO, 2020c).

"Call for international cooperation to prepare a united response, since the impact of the crisis will go far beyond tourism, the UNWTO slogan was accepted $\ll$ Stay home today, but travel tomorrow >>" (UNWTO, 2020d).

The various services in the tourism sector are made up of " $80 \%$ of small and medium-sized companies" which are in a situation of job loss whereas, "historical resilience of tourism and its ability to create employment after crisis situations depends on them" (UNWTO, 2020e).

"Managing the crisis and mitigating the impact; it refers to maintaining employment and supporting workers, ensuring liquidity and promoting skills development, as well as reviewing taxes, fees and regulations" (UNWTO, 2020f)

"Providing incentives and accelerating recovery by stressing the importance of providing financial stimuli, favorable fiscal policies, easing of the visa regime, taxes on marketing and consumer confidence" (UNWTO, 2020g).

To get ready for tomorrow, it is necessary to highlight the exceptional capacity of tourism to lead growth at the local and national level, therefore more attention must be paid to the Agenda for Sustainable Development and strengthening of resilience, learning from the lessons of the current crisis (UNWTO, 2020h).

\section{METHODOLOGY MATERIALS AND METHODS}

After a crisis, tourist destinations tend to face image problems, because they are affected by a series of factors, for an adequate recovery process the "Multi-step model" proposed by Avraham $(2013,2016,2018)$ is used, which is based on the classification of qualitative information, such as official reports, news reports, stakeholder mapping and direct information gathering tools, to generate proposals for improvement of the tourism sector during the crisis.

In this case, the subject of study is determined by the companies of the tourist sector of the city of Manta, Manabí, Ecuador, which are the most affected by the mandatory isolation that has stopped commercial activities caused by the quarantine and the closure of international borders. The total number of establishments registered in the city amounts to 569 , according to the latest land registry updated in early 2020.

The information presented below is the result of the suggestions given by tourism entrepreneurs and businessmen, which were obtained by a tool in the form of a questionnaire with open questions, designed in Google Forms, the survey was carried out via online, for which two ways of dissemination were used, the first directly through emails to managers and owners of the establishments; and the second through WhatsApp groups of various associations (restaurants, hotels, travel agencies, among others), where a large number of small entrepreneurs are active members, all of these organizations attached to the Decentralized Autonomous Government (GAD) of Canton Manta . A simple random sampling was performed taking into account all the establishments registered in the land registry, obtaining a representative sample of $48 \%$ (272) of the total population (López-Guzmán, Borges, \& López, 2012).

Content Analysis method processed on ATLAS ti program, version 8.4 was used for the qualitative analysis of this information, the survey responses were entered, through deductive and inductive analysis using the rooting (coincidences) of the information, 360 citations were obtained from the answers, due to the fact that one answer could give several citations, which were labeled by codes, and these, in turn, as strategies or similar suggestions proposed by the respondents for the revival of the business sector.

Likewise, these codes (strategies) were grouped according to their orientation, to whom they were repetitively directed (density), deriving into two classification: on the one hand, group 1 (strategies addressed to the authorities) and group 2 (strategies specific to the sector). Relationships between codes were analyzed by building networks, which also served to efficiently illustrate the result of the information collected. 


\section{RESULTS AND DISCUSION}

\section{Geographical description of the tourist destination of Manta}

Manta, officially called San Pablo de Manta. It is one of the most important cities in Ecuador and has the first tourist, sea and fishing port, with a privileged geo - strategic location for cruise tourism and maritime trade in the region. Belongs to Ecuador's national strategic planning zone 4 (see figure 1). This territory conserves important natural and cultural resources, declared the First Tourist Municipality of Ecuador in 1999. The Mantenses, the last pre-Columbian civilization established all around the canton geography, were famous for their pottery and navigation skills. Today, the demand for sun and beach tourism (Lima, 2013) is increasingly diversified in this destination and is one of the main economic segments in Manta, the concentration of public resources, private investments and tourist flows is mainly perceived from the provinces located in the highlands of Ecuador.

The canton has undergone an accelerated process of occupation, urbanization, relevant industrial and port activities and large-scale tourist exploitation (GAD Autonomous and Decentralized Government of the canton of Manta, 2019).

Figure 1. Political-administrative territorial division map Planning Zone 4 Pacific.

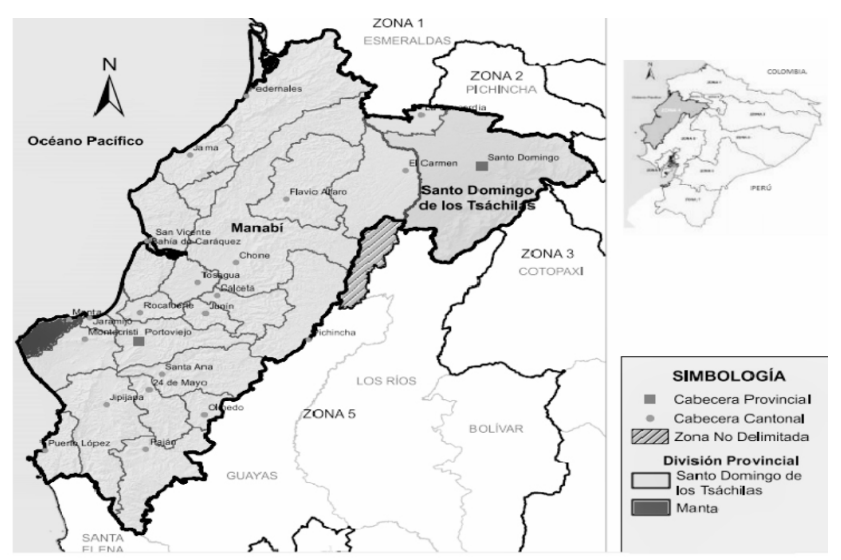

Fuente: National Secretariat for Planning and Development of Ecuador, 2015.
Domestic tourism predominates in the Manta canton, exceeding $90 \%$ according to data provided by local hotels where they record the guests' nationality. For this reason, it is important to base advertising on this important segment, as well as increase advertising in the country's receptive market. One-day visitors continue to be the one with the highest percentage (67.49\%), differentiating it from the tourist who stays overnight (32.51\%) since Manta is considered a distribution point to destinations, such as Canoa in the north and Puerto López in the south of the province, (Autonomous and Decentralized Government GAD of the canton of Manta, 2019).

\section{Participatory diagnosis of the tourism sector}

The results obtained allow to diagnose the current business situation of tourist establishments, and project their post-COVID-19 recovery strategies.

The results are shown in three sections in chronological order, according to how they were obtained. Firstly, the codes (strategies) obtained are explained as they were grouped, secondly, the groups of codes based on the orientations of the responses by the entrepreneurs (groups of strategies) and finally, the relationships among elements through networks or matrices obtained from the program. Codes (Strategies)

Fourteen codes (strategies) were identified, which were grouped according to the orientations of the responses by tourist entrepreneurs and businessmen, these exceed the number of samples (see table 2), because the responses, were open, broad and contained several options of responses per individual surveyed.

Table 2. Coding and rooting of strategies.

\begin{tabular}{llc}
\hline CODE & \multicolumn{1}{c}{ STRATEGY } & ROOTING \\
\hline C1 & Tributary & 53 \\
C2 & Healt/Safety & 44 \\
C3 & Destination management & 42 \\
C4 & Gobernance/Legal & 42 \\
\hline C5 & Credits & 33 \\
C6 & Marketing/Products & 32 \\
C7 & Promotion/Advertising & 29 \\
\hline C8 & Customer support & 18 \\
C9 & Incentives & 17
\end{tabular}




\begin{tabular}{lll} 
C10 & Associativity & 16 \\
C11 & Planning & 12 \\
\hline C12 & Training & 10 \\
C13 & Supplies & 8 \\
C14 & Research & 4 \\
\hline & TOTAL & $\mathbf{3 6 0}$ \\
\hline
\end{tabular}

Source: Self-reported information.

As a result of the codification and rooting of the strategies, businessmen request with greater recurrence (rooting), strategies oriented to the suspension and taxes forgiveness, both towards local organizations (GAD) and National Ministry of tourism (MINTUR). Secondly, they emphasize health, such as the implementation of good practices in establishments and the positioning of the image of the Manta destination as a safe place before COVID-19. This accompanied by public regulations that promote the formality of the industry, eliminating the indices of informal companies in the market.

The analysis enables to define strategies -at a next leveladdressing the importance of the generation of soft loans, or refinancing past-due loans, as a way to oxygenate small and medium-sized companies; consequently, the strategies are related to the creation of new products, especially with those inclined to nature, in order to replace the existing sun and beach model in the tourist destination of Manta, which has management limitations that make it unsustainable. Other strategies also emphasize the creation of technological platforms that contribute to the commercialization and promotion of tourist products of the destination, directed and integrated to issues of diversity, nature, rurality and, above all, health.

Lastly, strategies with less roots but of similar importance were found, those that promote topics such as training of human talent in health issues, joint business work as a possible subsistence strategy, the generation of quality certifications, both for good service and bio-security processes in tourist businesses. This last strategy is transcendent as Dwyer \& Kim (2003) stated that security and protection within a destination can be a critical factor for competitiveness.

Encouraging good practices with economic benefits is also part of the most relevant suggestions from entrepreneurs and businessmen. The establishment of continuous research to monitor market trends in order to guide the actions of local companies towards the needs of the future tourist. In addition to having new sources of logistics supply, especially based on rural communities located in the periphery, which would serve as a double development path, both to ensure local supply and to generate income for the communities.

\section{Code groups (strategies group)}

These codes were also analyzed among themselves, depending on the relationships or orientations their answers had (density). For example, when suggesting that "Manta has to be promoted as a safe destination", it was double codified, in destination management and health / safety, this suggestion became part of the group of strategies aimed at authorities; Otherwise, if the suggestion was " to implement disinfection booths in establishments", this was labeled health / safety, but became part of the group of strategies aimed at the establishments themselves, therefore, repeated codes can be found in both groups, but the orientation and relationships of its components are different and this will be illustrated later in the networks or final relationship matrices of these strategies, hereafter the description of how the code groups were formed is shown. (see figure 2).

Group 1: All suggestions taken from the responses by tourism entrepreneurs and businessmen, addressed to local or national authorities.

Group 2: All the suggestions taken from the responses by the tourist entrepreneurs, directed at themselves and the improvement of their establishments.

Figure 2. Codes grouped according to the orientation of the suggestions.

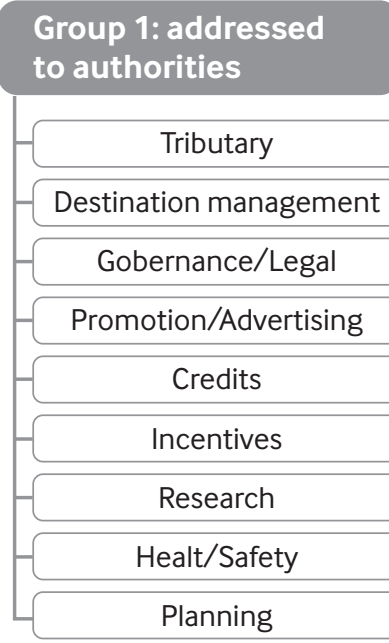

Group 2: addressed sector-specific

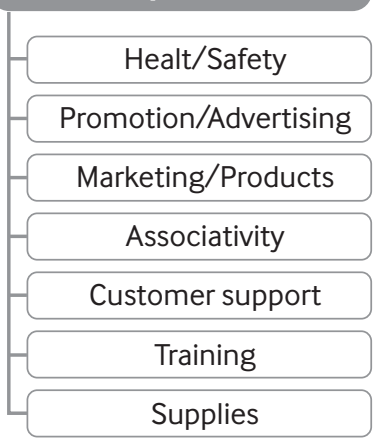

Source: Self-reported information. 
To finish understanding the analysis conducted, which will serve as the basis for decision-making by local governments, it is necessary to understand the interrelationships between these two groups of codes (strategies) addressed, and how they will serve for the implementation of joint actions with tourism entrepreneurs in the territory. Such relationships and their practical applicability are illustrated in the following section.

\section{Networks (relationship maps)}

The structuring of networks is a graphic method by which the program used for qualitative analysis tries to explain -in an explanatory and graphic way- the relationships between the codes identified as strategies. These relationships were analyzed through structured figures such as concept or relationship maps (see Figures 3 and 4) arranged according to each of the code groups.

Figure 3. Map of relationships between group 1 strategies (addressed to authorities).

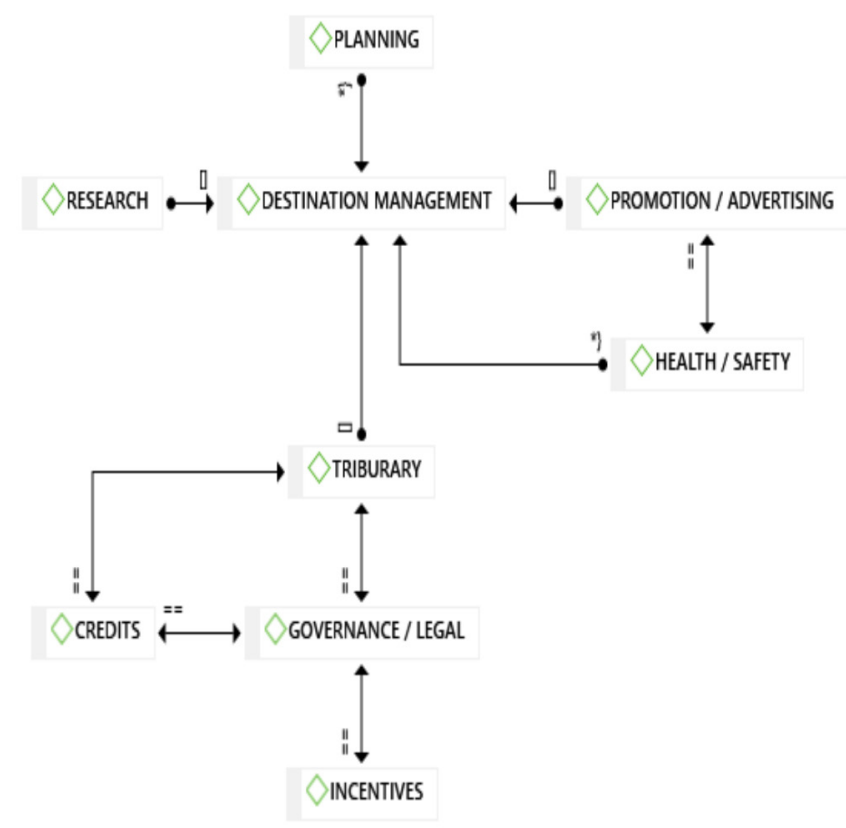

Source: Self-reported information.
As shown in figure 3 , in the relationships between the codes of group one, there is a high relationship of the strategies with respect to the code corresponding to destination management. The codes corresponding to promotion and health are highly related to each other and therefore to destination management, mainly because many of the suggestions are aimed at promoting Manta as a healthy and safe destination. On the other hand, there are other elements with a strong relationship such as: tax, credit and local governance incentives, since high emphasis is placed on the financial support that must exist for the sector, in connection with municip al ordinances proposed by the local government for the support and elimination of informal businesses

Figure 4. Map of relationships between group 2 strategies (self-addressed to the entrepreneurs)

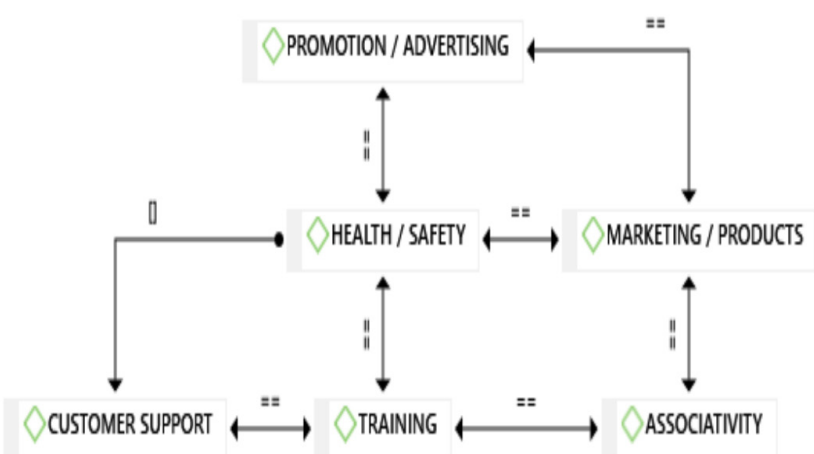

Source: Self-reported information.

As shown in Figure 4, the relationships between the sector's own strategies are strongly related to safeguarding health within tourist establishments. There is a strong relationship between commercial issues and associativity, which is very consistent, and reaffirms what was stated by (March-Navarro, 2017) when considering that networking works inculcate cultural principles and norms, strengthening shared values and reaffirming the local identity. This allows the empowerment of individuals in the community, by being part of the tourism product offered.

This crisis shows that one of the business strategies to be promoted is associativity aimed to guarantee small businesses their permanence in the tourism market, this fact corroborates the theories reviewed in the scientific literature on the development of networks in tourism, regardless of its type, due to its capacity to generate a series of benefits, amongst which the tourism-related companies 
in the local context stand out; as they mediate and guide the commitments and investment decisions necessary to develop sustainable and complementary forms of tourism; facilitate access to existing resources; and assist the integration of companies through coordination mechanisms (Marzo-Navarro, 2017)

On the other hand, marketing strategies are another identified aspect that must be taken into account, because they facilitate the positioning of the Manta tourism product; which in the view of Reinoso \& Quintero (2018) they must be applied in a way that their design structure is optimal and acceptable; in order to make it possible to provide a better and safer customer service, it guarantees the satisfactory fulfillment of their needs and expectations, in addition to mitigating possible customer's concerns with great professionalism, concurring with Dwyer \& Kim (2003), who asserts that the issues of security and protection are now firmly established as key elements of destination competitiveness.

In order to perform thorough work that provides a clear response to the problem, all codes, groups of codes and networks were built according to the suggestions from the Manta canton tourism business sector. This methodology has the capacity to cover each and every one of the suggestions issued by the tourism entrepreneurs and businessmen of the territory, without the inclusion of any additional variable to discriminate or segment the responses, and also it allows an expedited diagnosis, which shows the main problems and demands of the tourism sector, independent of the communicational limitations at the present moments, caused by the pandemic.

In this regard, all the information concerning the effects caused by this COVID-19 pandemic in the tourism sector, which was stated by managers, businessmen, entrepreneurs, and actors in general, through the application of the aforementioned techniques, as well as the other obtained by means of other techniques or sources, were very valuable; likewise official reports, statistics from the governing bodies that rule this activity in the country, added to measures to mitigate the effects. Despite these state institutions have not been opportune in pronouncing practical guidelines up to now.

The perception of tourists is another important information to take into account; However, they were not included in this study, since it was considered that the information that could be obtained at the present time could be unreliable, since tourists are in a state of isolation, sheltered in hotels, residences and family and friends homes, in a state of survival. It is considered necessary to keep on with these types of studies on a continuous basis by the time social isolation; since a radical change in travel trends is expected and it is urgent in the agenda of local authorities in the territory to learn the motivations and demands of travelers, as well as the new behaviors that constitute important inputs for the identification and implementation of new tourism development strategies, especially to guide new tourist vocations in unconventional sectors such as rural areas.

\section{CONCLUSIONES}

Security is one of the most important aspects for the development of tourism (Cruz \& López, 2016). The importance of security is related to health, food, legal security against robberies or attacks, natural catastrophes, etc. Each destination has its own problems and characteristics that make them different from one another, therefore the provisions must be put into practice taking into account these same principles.

In the midst of this pandemic, it is necessary to identify the current needs of the business sector in tourist destinations, for this end, it is essential to determine the strategies that comprise knowledge of the environment and the current situation to anticipate possible changes and guide the destination, company and organization, in a way that allows them to make right decisions and meet the objectives. On the other hand, the need for security, along with the physiological needs for food and help, represents the main motivating forces behind human behavior. If potential visitors are very concerned about crime, the quality of drinking water, the risk of natural disasters, the standards of medical services, etc., other competitive strengths may be few in the minds of these people (Ritchie \& Crouch , 2010).

For Pulido \& López (2013), the government is in charge of promoting and coordinating major political decisions, performing social leadership, managing crises and directing, coordinating and supervising the services of the administrations that help it in this task. In this context, the present work is the product of the actions developed by the technical committee for tourist reactivation; implemented by the Decentralized Autonomous Government of the Manta Canton, as a result of this health crisis, which in a strategic partnership for tourism development, has granted the 
guarantee of participation to the Agricultural Polytechnic University of Manabi Manuel Felix Lopez (ESPAM MFL).

The methodology used in this research, through the elaboration and application of a simple open-response questionnaire and its qualitative processing through the use of the ATLAS ti program, version 8.4, can be very useful at the moment, especially in the business sphere, since these actors are urged to communicate the problems that affect them in their environment; It also allows them to propose possible solutions themselves. These suggestions for possible actions provided by the actors can guide both local authorities and themselves in decision-making, it is essential for the survival of many small and medium-sized entrepreneurships in the market, since their managers, in some cases, have limited management experience.

The processing of qualitative information through the use of the ATLAS ti program, version 8.4, has proven to be very efficient, since it has allowed the information collected to be optimally grouped, and enabled the researchers to identify 14 codes, 2 groups of codes and illustrate all the existing relationships among them through 2 networks, with possible inclinations to certain strategies such as: destination management and health / safety, which can serve as a basic element in short-term planning.

Reinoso (2017) considers that implementing strategies guided under an effective management model is essential within governance processes, in activities that benefit the locality in general. The results allow to identify the existence of three levels of strategies based on the rooting of the responses, very clearly oriented by the entrepreneurs. The first covers codes related to tax strategies, health / safety, destination management, governance / legal; which can be translated into tax exemption, implementation of good sanitary practices, promotion of a healthy destination and ordinances that support formal business strengthening.

At the second level, there are above-average rooting of credit strategies, marketing / products, promotion / advertising, which can be translated into soft loans, new innovative products and better advertising for these products.

At the third level, the last group of strategies are found, which have less rooted responses, but are still important, such as: customer service, incentives, associativeness, planning, training, supply and research. These result in customer loyalty to certified establishments for good practices, associativeness in the creation or promotion of collaborative products, new skills training of the staff, alternatives for local and community supply and, finally, continuous research on market needs, both from the perspective of supply and demand.

These results of the third level highlight associativity as a key strategy, and corroborate the theories addressed in the scientific literature on tourism about the necessary associativity between different tourism organizations, working together on aspects of tourism commercialization, formalization of undertakings, and training or technical assistance, in order to contribute to the positioning of the private sector and the community in the development process (Reinoso, 2017). The business sector of the city of Manta needs to organize its proposals and work on them in an integrated way with the local authorities. Unlike other crises, the recovery of destinations after the COVID-19 pandemic will depend on the organization of the territories and the joint work between the public sector, private companies and academia.

Universities must create new research areas related to the consequences and solutions of COVID-19, they must also include crisis management in their curricula of tourism careers, which will serve as a support for the gearing of the actions in the territory. Moreover, it is necessary to create crisis committees in the territories, which must bring together representatives of the different tourism sectors, to carry out joint planning for the reactivation of tourism in the short, medium and long term.

\section{ACKNOWLEDGEMENTS}

This work is the result of the research carried out by the technical committee for tourist reactivation, implemented by the Decentralized Autonomous Government of the Canton of Manta, in the face of the health crisis caused by COVID-19, in a strategic partnership with the Agricultural Polytechnic University of Manabi Manuel Felix Lopez (ESPAM MFL), for the tourist development of the territory.

\section{REFERENCES}

África Research Bulletin. (2014). Political Social and Cultural Series, 51(11), 1-7.

Arrazola, M. P., Serrano, A., \& López-Vélez, R. (2016). Vaccination for international travelers. Enfermedades Infecciosas y Microbiologia Clinica, 34(5), 315323. https://doi.org/10.1016/j.eimc.2016.01.009 
Autonomous and Decentralized Government GAD of the canton of Manta. (2019). Territorial development and planning plan with special emphasis on risk management, Manta canton. Retrieved from Gobierno Autónomo y Descentralizado GAD del cantón Manta website: https://www.manta.gob. ec/index.php/publico/pdot-2014-2019?download=3596:PDYOT GAD MANTA F

Avraham, E. (2013). Crisis Communication , Image Restoration, and Battling Stereotypes of Terror and Wars: Media Strategies for Attracting Tourism to Middle Eastern Countries. 1-18. https://doi. org/10.1177/0002764213487733

Avraham, E. (2016). Destination marketing and image repair during tourism crises: The case of Egypt. Journal of Hospitality and Tourism Management, 28, 4148. https://doi.org/10.1016/j.jhtm.2016.04.004

Avraham, E. (2018). Nation branding and marketing strategies for combatting tourism crises and stereotypes toward destinations. Journal of Business Research, (February), 0-1. https://doi.org/10.1016/j. jbusres.2018.02.036

Basurto-Cedeño, E. M., \& Pennington-Gray, L. (2018). An Applied Destination Resilience Model. Tourism Review International, 22(3), 293-302. https://doi. org/10.3727/154427218×15369305779092

Birkland, T., Pannapa, H., Little, R., \& Wallace, W. (2006). The Thailand Tsunami and Hurricane Katrina: A Preliminary Assessment of Their Impact and Meaning in Global Tourism. In Rutgers university (Ed.), The future of disasters in a globalizating world .

Cortés, M. (2019). Corona Virus Disease 2019 (COVID-19): the importance of being alert to zoonoses. Medical University Journal of Antioquia,1-13. https://doi. org/.1037//0033-2909.126.1.78

Crouch, G., \& Ritchie, J. (1999). Tourism, Competitiveness, and Societal Prosperity. Journal of Business Research, 44(3), 137-152. https://doi. org/10.1016/S0148-2963(97)00196-3

Cruz, M., \& López, E. (2016). Is there a Canarian tourist model? (First Ed; V. de R. with the S. of the U. of L. L.
/ C. of T. CajaCanarias-Ashotel-ULL, Ed.). CANARIAS: PROMOTUR TURISMO CANARIAS, S.A.

Dávila, M., Arambu, C., Morte, S., Vera, I., Inglesias, M., \& González, Ó. (2010). Border control and surveillance. Role of external health during the containment phases of the pandemic (H1N1) 2009. Spanish Journal of Public Health, 84, 507-516. Retrieved from https://scielosp.org/article/ssm/content/ raw/?resource_ssm_path=/media/assets/resp/ v84n5/colaboracion4.pdf

De Sausmarez, N. (2004). Crisis Management for the Tourism Sector: Preliminary Considerations in Policy Development. Tourism and Hospitality Planning \& Development, 1 (2), 157-172.

Dwyer, L., \& Kim, C. (2003). Destination Competitiveness: Determinants and Indicators. Current Issues in Tourism Destination, 6(5), 369-414. https://doi. org/10.1080/13683500308667962

Evans, N. \& Elphik, S. (2005). Models of Crisis Management and Evaluation of their Value Strategic Planning in the International Travel Industry. International Journal of Tourism Research, 7, 135-150.

Faulkner, B. (2001). Towards a framework for tourism disaster management. Tourism Management. https://doi.org/10.1016/S0261-5177(00)00048-0

Félix, A., Campos, S., Martí, J., \& Ramos, M. (2017). Recovery of post-earthquake tourist destinations: review of the Ecuador case. Venezuelan Journal of Management, 80, 638-657.

Guardia, F. (2020). What is the impact of epidemics on the world economy? Retrieved April 15, 2020, from https://www.ey.com/es_ec/future-health/impacto-de-las-enfermedades-en-la-economia-mundial

Jamal, T., \& Budke, C. (2020). Tourism in a world with pandemics: local-global responsibility and action. Journal of Tourism Futures, ahead-of-p(ahead-of-print). https://doi.org/10.1108/jtf-02-2020-0014

Ledermann, W. (2003). Man and his epidemics throughout history. Chilean Journal of Infectology, 
20, 13-17. https://doi.org/10.4067/s071610182003020200003

Leggat, P. A., Brown, L. H., Aitken, P., \& Speare, R. (2010). Level of concern and precaution taking among australians regarding travel during Pandemic (H1N1) 2009: Results from the 2009 Queensland social survey. Journal of Travel Medicine, 17(5), 291-295. https://doi.org/10.1111/j.17088305.2010.00445.x

Lima, L. (2013). Impacts of sun and beach tourism in the southern coast of Sergipe, Brazil. Tourism Studies and Prospects, 22, 526-545.

López-Guzmán, T., Borges, O., \& López, J. M. (2012). Analysis of tourism supply and demand on the island of Sal, Cape Verde. Rosa Dos Ventos, 4(4), 469-485.

Maphanga, P. M., \& Henama, U. S. (2019). The tourism impact of ebola in Africa: Lessons on crisis management. African Journal of Hospitality, Tourism and Leisure, 8(3).

Marzo-Navarro, M. (2017). Development of integrated rural tourism from the perspective of residents: proposed model. Journal of Tourism and Cultural Heritage.15(4), 841-859.

National Secretariat for Planning and Development of Ecuador. (2015). Zonal Agenda ZONE 4-Pacific. Retrieved from http://www.planificacion.gob.ec/ wp-content/uploads/downloads/2015/11/Agenda-zona-4.pdf

Oehmichen, C., \& París Pombo, M. (2010). Fear of global risk: Notes on the emergence of the a / H1N1 virus and tourism. Journal of New Trends in Anthropology, (1), 8.

Paraskevas, A., \& Altinay, L. (2013). Signal detection as the first line of defence in tourism crisis management. Tourism Management, 34. https://doi.org/10.1016/j.tourman.2012.04.007

Pennington-Gray, L.; Cahyanto, I.; Cahyanto, B.; Thapa, B.; McLaughlin, E.; Willming, C. y Blair, S. (2010). Destination Management Organizations and Tou- rism Crisis Management Plans in Florida. Tourism Review International, 13, 247-261.

Pulido, J. I., \& López, Y. (2013). Sustainable strategic management of tourist destinations. Seville: International University of Andalusia, Publications Service.

Reinoso, N. (2017). Management model to promote tourist development of the Manabitian communities, Ecuador. CULTUR - Journal of Culture and Tourism, 11(2), 81-108.

Reinoso, N., \& Quintero, Y. (2018). Sun and beach product for the tourist development of the Municipality of Trinidad de Cuba. Inter-American Journal of Environment and Tourism. (RIAT), 14(1), 52-64. https:// doi.org/10.4067/s0718-235x2018000100052

Ritchie, B. W. (2004). Chaos, crises and disasters: A strategic approach to crisis management in the tourism industry. Tourism Management. https://doi. org/10.1016/j.tourman.2003.09.004

Ritchie, J., \& Crouch, G. (2010). A model of destination competitiveness/ sustainability : Brazilian perspectives. Public Administration Review (RAP), 44(5), 1049-1066.

Rivera, M., \& Félix, Á. (2019). Strategic planning and governance in the recovery of touristic destinations affected by unnatural disasters. State of the question. Revista Investigaciones Geográficas, 72.

Rodríguez-Morales, A. J., Gallego, V., Escalera-Antezana, J. P., Méndez, C. A., Zambrano, L. I., Franco-Paredes, C., ... Cimerman, S. (2020). COVID-19 in Latin America: The implications of the first confirmed case in Brazil. Travel Medicine and Infectious Disease, 101613. https://doi.org/10.1016/j.tmaid.2020.101613

Rodríguez-Morales, A. J., MacGregor, K., Kanagarajah, S, Patel, D. \& Schlagenhauf, P. (2019). Going global Travel and the 2019 novel coronavirus. Travel Medicine and Infectious Disease; 33:101578.

UNEP (United Nations Environment Program) (2008). Disaster Risk Management for Coastal Tourism Destinations Responding to Climate Change. A Practical Guide for Decision Makers. Washington: UNEP. 
United Nations Development and Environment Programs (UNDP-UNEP) (2008). Panorama of the environmental impact of recent natural disasters in Latin America and the Caribbean. Washington: UNDP-UNEP.

UNWTO (World Tourism Organization). (2020). World Tourism Barometer (Vol. 18). Retrieved from https:// www.e-unwto.org/doi/pdf/10.18111/wtobarometeresp.2020.18.1.1

UNWTO. (2020a). World Tourism Barometer (Vol. 18). Retrieved from https://www.e-unwto.org/doi/ pdf/10.18111/wtobarometeresp.2020.18.1.1

UNWTO. (2020b). Joint Declaration on Tourism and covid-19, UNWTO and WHO call for accountability and coordination. on: https://www.unwto.org/es/ news/covid-19-omt-oms-Ilamamiento-a-la-responsabilidad-y-la-coordinacion.

UNWTO. (2020c). Covid-19: setting people first. Tourist sector and covid-19. on: https://www.unwto.org/ es/turismo-covid-19.

UNWTO. (2020d) UNWTO Declaration on the Outbreak of the New Coronavirus. January 31, 2020, on: https:// www.unwto.org/es/declaracion-de-la-omt-sobre-el-brote-del-nuevo-coronavirus.

UNWTO. (2020e). COVID-19: UNWTO calls for tourism to be included in recovery plans. On: https://webunwto.s3.eu-west-1.amazonaws.com/s3fs-public/2020-03/nr\%20-\%20covid19_es.pdf
UNWTO. (2020f). UNWTO Convenes a World Crisis Committee for Tourism. March 20, 2020, en: https:// www.unwto.org/es/omt-convoca-un-comite-mundial-de-crisis-para-el-turismo.

UNWTO. (2020g). UNWTO: International tourist arrivals may drop $20-30 \%$ in 2020. March 27, 2020, on: https://www.unwto.org/es/news/ omt-las-llegadas-de-turistas-internacionales-podrian-caer-2020.

UNWTO. (2020h). UNWTO launches a call to action for the mitigation of the impact of COVID-19 on Tourism and Recovery of the Sector. April 1, 2020,en: https://unwto.org/es/news/apoyo-al-empleo-y-a-laeconomia-a-traves-de-los-viajes-y-el-turismo.

WHO (World Health Organization). (2020). WHO advice on international travel and trade related to the outbreak of pneumonia caused by a new coronavirus in China, January 10, 2020, on: https://www.who.int/ith/20200901_outbreak_of_Pneumonia_caused_by_a_new coronavirus_in_Cles/

Wilks, J. y Moore, S. (2003). Tourism Risk Management for the Asia Pacific Region: An Authoritative Guide for Managing Crises and Disasters. Singapur: PATA y APEC.

Zeng, B., Carter, R. W., \& De Lacy, T. (2005). Shortterm perturbations and tourism effects: The case of SARS in China. Current Issues in Tourism, 8(4), 306-322. https://doi. org/10.1080/13683500508668220 